\title{
Ability or Finances as Constraints on Entrepreneurship? Evidence from Survival Rates in a Natural Experiment.
}

\author{
Steffen Andersen \\ Department of Economics, Copenhagen Business School
}

Kasper Meisner Nielsen

Department of Finance, Hong Kong University of Science and Technology

\begin{abstract}
We use a natural experiment in Denmark to test the hypothesis that aspiring entrepreneurs face financial constraints because of low entrepreneurial quality. We identify 304 constrained entrepreneurs who start a business after receiving windfall wealth and examine the performance of these marginal entrepreneurs. We find that constrained entrepreneurs have significantly lower survival rates and lower profits when compared with a matched sample of unconstrained entrepreneurs. These results are consistent with the hypothesis that the marginal entrepreneur is of low quality. (JEL J23, L26, M13)
\end{abstract}

Entrepreneurship plays an important role in job creation and economic growth. Because of these positive externalities, many countries have established policy programs and agencies aimed directly at encouraging entrepreneurship. Financial constraints are among the most-cited impediments to entrepreneurship If financial constraints are binding, low-wealth households will be constrained from starting businesses. Such constraints result in less entrepreneurial activity

\footnotetext{
We thank Thea Yde Jensen and Julie Marx for excellent research assistance. For helpful comments and suggestions, we are grateful to an anonymous referee and Henk Berkman, Christophe Bonnet, Martin Browning, Sudipto Dasgupta, Mette Ejnæs, Eithan Goldman, Glenn Harrison, Hans Hvide, Alexander Ljungqvist (the editor), and Chandler Lutz, as well as seminar participants and colleagues at the Academy of Entrepreneurial Finance 2011 Meeting, Deakin Finance Colloquium 2011, the European Finance Association 2011 Meeting, Hong Kong University of Science and Technology, Singapore Management University, University of Bergen, University of Copenhagen, and University of East Anglia. This work was supported by the Danish Social Science Research Council [grant number 09-065449]. Send correspondence to Steffen Andersen, Department of Economics, Copenhagen Business School; Porcelænshaven 16A, 2000 Frederiksberg, Denmark; telephone: +45 3815 2591. E-mail: sa.eco@cbs.dk. Kasper Meisner Nielsen, Department of Finance, Hong Kong University of Science and Technology, Clear Water Bay, Kowloon, Hong Kong; telephone: +852 2358 7683. E-mail: nielsen@ust.hk.

1 Surveys of current and aspiring entrepreneurs suggest that obtaining financing is one of the principal hurdles to forming and growing new businesses Blanchflower and Oswald 1998). Not surprisingly, access to financing is high on the policy agenda around the world. In the United States, for example, the Small Business Administration has, since 1954, delivered millions of loans and guarantees for bank loans to facilitate the financing of small businesses. Many OECD countries are also encouraging entrepreneurship by easing access to financing (see OECD 2010] for an overview of policies across countries).
}

(C) The Author 2012. Published by Oxford University Press on behalf of The Society for Financial Studies. All rights reserved. For Permissions, please e-mail: journals.permissions@oup.com. doi:10.1093/rfs/hhs107

Advance Access publication October 15, 2012 
and, in turn, lower economic growth. Consequently, policy initiatives have often attempted to ease access to financing.

The question of why aspiring entrepreneurs face financial constraints is natural. If financial constraints are imposed by well-functioning capital markets, we expect the marginal entrant to be of lower quality than is the average entrepreneur. In this study, we use a natural experiment to test the hypothesis that the marginal entrant is of low quality. We test this hypothesis under the assumption that differences in quality will show up as differences in outcomes measured by performance. We use exogenous variation in wealth resulting from unanticipated inheritance due to sudden death to identify constrained entrepreneurs (i.e., individuals who become self-employed after receiving windfall wealth); we then assess their performance in relation to a matched sample of unconstrained entrepreneurs (i.e., individuals with similar characteristics who became self-employed in the same period but who did not receive windfall wealth). To measure performance, we examine survival rates, entrepreneurial profits, and total income.

Our results reveal that constrained entrepreneurs perform significantly worse than do unconstrained entrepreneurs. After one (five) year(s), only $64.1 \%$ $(41.9 \%)$ of the constrained entrepreneurs stay in business. In comparison, $75.0 \%(50.0 \%)$ of the unconstrained entrepreneurs in the control group stay in business. We also find lower performance when we examine entrepreneurial profits and total income using detailed data from the Danish Tax Authorities. On average, entrepreneurial profit is $22 \%$ to $39 \%$ lower for the constrained entrepreneurs over the first five years after establishment, whereas total income in the same period is $5 \%$ to $20 \%$ lower for constrained entrepreneurs. The combination of lower survival rates, lower entrepreneurial profit, and lower total income supports the hypothesis that the marginal quality of constrained entrepreneurs is lower than that of unconstrained entrepreneurs.

Although our results are consistent with the hypothesis that the marginal entrepreneur is of low quality, the main weakness of our approach is that we cannot rule out confounding effects related to inheritances. Although our experiment imposes no selection of beneficiaries, except in the event of sudden death, entry into entrepreneurship is positively affected by inherited wealth. The treatment effect might therefore be confounded by a wealth effect that potentially can explain our results. To separate the treatment effect from a wealth effect, we use entrepreneurs whose parents suddenly die shortly after business formation as counterfactual in our experiment. In this setting, constrained entrepreneurs receive windfall wealth before they become self-employed, whereas unconstrained entrepreneurs receive the windfall shortly after business formation. We find that constrained entrepreneurs underperform both before and after unconstrained entrepreneurs receive windfalls. This finding effectively rules out the likelihood that our treatment effect is confounded by a wealth effect.

Overall, we find that constrained entrepreneurs have significantly lower survival rates, lower entrepreneurial profits, and lower total income when 
compared with a matched sample of unconstrained entrepreneurs. We use a competing risk model to show that the lower survival rates are driven by higher failure rates among constrained entrepreneurs. We also show that differences in entrepreneurial profits and total income are not driven by efficient stopping rules or a direct effect of wealth on performance. Collectively, these results are consistent with the hypothesis that the marginal entrepreneur is of low quality.

Our results offer an alternative interpretation of why aspiring entrepreneurs, when questioned in surveys, say that raising financing is their principal problem Blanchflower and Oswald 1998). Consistent with the existence of financial constraints, prior literature documents a positive correlation between the propensity to become an entrepreneur and individual wealth (Evans and Jovanovic 1989:|Evans and Leighton 1989:|Fairlie 1999: Ouadrinil 1999: Gentry and Hubbard 2001) or exogenous variation in wealth due to inheritance or lottery winnings (Holtz-Eakin. Joulfaian, and Rosen 1994b; Lindh and Ohlsson 1996;:Blanchflower and Oswald 1998). Although these studies demonstrate that low-wealth households are excluded from capital markets, this observation does not imply that policy makers should make loans easier to come by. De Meza 2002) shows that encouraging entry into entrepreneurship shifts individuals with negative net present value undertakings into business. Subsidizing credit may decrease efficiency because it offsets the disciplining role of capital markets. The barrier to firm formation might therefore be low entrepreneurial quality rather than access to financing. Direct empirical evidence on the disciplinary role of external financing is scant. A recent exception is Nanda 2008), who shows that entry subsequently dropped after a tax reform in Denmark that made external financing more expensive. Similarly, Hvide and Møen (2010) and Nanda (2011) show that the quality of wealthy entrants is lower because wealthy entrants do not face the discipline of the external market. In comparison, we assess the quality of the marginal entrant by studying individuals who start a business after receiving windfall wealth.

Our study contributes to the literature by using a natural experiment to test the hypothesis that the quality of the marginal entrant is low. We thereby challenge the premise behind policies that facilitate broad access to financing: Frictions in the capital markets preclude entrepreneurs with good ideas from starting a new business. Our results question the welfare gains from promoting entrepreneurship among constrained individuals. Positive externalities from entrepreneurship on job creation and growth King and Levine 1993a, 1993b) are less likely to materialize if the marginal entrepreneur is of low quality.

Our results, however, do not imply that all individuals with worthy projects will obtain financing. Frictions in the capital markets might prevent some entrepreneurs with good projects from starting a new business, and lenders might find it optimal to ration their access to capital. For instance, Stiglitz and Weiss (1981) present a model in which banks use the interest rate as a screening device. As a result, aspiring entrepreneurs with safer projects are discouraged from starting their businesses. Alternatively, local banking monopolies might 
limit access to financing for start-ups and subsequently distort entrepreneurship Kerr and Nanda 2009, 2010). Our results also do not preclude the prevalence of lender discrimination against certain individuals. Nevertheless, our results suggest that the rationale for initiatives to promote wider entrepreneurship should focus on eliminating the cause of frictions or discrimination rather than on providing broad access to financing.

Section 11 presents our data and provides summary statistics. Section 2 presents the results, and Section 3 separates the treatment effect from possible wealth effects. Section 4 concludes.

\section{Windfall Wealth from Unexpected Inheritance Due to Sudden Death}

We exploit exogenous variation in individual wealth to test the hypothesis that entrepreneurs face financial constraints because of low entrepreneurial quality. Exogenous variation in wealth is derived from a natural experiment in which individuals receive windfall wealth because of the sudden death of their legal parents. For the identification strategy to work, the death event has to be unexpected and sudden 2 Sudden deaths are medically defined as an unexpected death that occurs instantaneously or within a few hours of an abrupt change in the person's previous clinical state 3 To this end, we have assembled a unique data set from Denmark that allows us to identify windfall wealth from unexpected inheritance and relate it to entrepreneurial activity.

In addition to supplying microdata from administrative registers, the Danish case also provides us with a legal environment that eases the identification of estates and their heirs. We focus exclusively on inheritance cases in which all beneficiaries are offspring (i.e., where the suddenly deceased was a widow or widower or, in rare cases, a couple). We refer to these cases as terminations of households. This designation simplifies the analysis, as children, according to the Danish Inheritance Law of 1964, will inherit by default the estate in proportional shares. Although opting out through wills is possible in Denmark, the inheritance law ensures that children will inherit at least $50 \%$ of the estate in the cases we consider. Only $2 \%$ of the empirically relevant individuals in Denmark have drafted a will Ret og Råd 2008). Consequently, the net wealth of the estates in our sample is divided equally among the offspring.

Identification of estates is facilitated by the institutional environment. Danish law requires that a death certificate be issued by a doctor when a citizen dies. Danish law further obliges the relatives to report the death to their local funeral authority within two days. The funeral authority formally notifies relevant

2 We also need the death event to be uncorrelated with omitted variables that affect the outcome variable, e.g., the decision to become an entrepreneur.

3 For instance, the American Academy of Pediatrics defines sudden cardiac death as a nontraumatic, nonviolent, and unexpected event resulting from sudden cardiac arrest within six hours of a previously witnessed state of normal health. 
government agencies, including the Central Office for Personal Registration (CPR Registeret) and the probate court (Skifteretten). Skifteretten supervises the process that transfers legal title of property from the decedent's estate to her beneficiaries. Skifteretten immediately seizes the decedent's assets, with the purpose of meeting liabilities, and transfers the net worth to the beneficiaries in accordance with the sharing rule established by the inheritance law. By law, the transfer of the decedent's estate has to be finalized within twelve months of the death. The net worth of the estate is subject to a $15 \%$ estate tax for offspring if the estate's net wealth exceeds DKK 191,000 (EUR 25,638) in 1998. This threshold is inflated by a price index in subsequent years.

\subsection{Data sources}

Our data cover the population of adult Danes in the period between 1995 and 2007. Our analysis will, however, focus on individuals who inherit in the period from 1995 to 2001 and, subsequently, start a business in the following year. This leaves a five-year evaluation period after firm formation to assess the outcome of the businesses. We construct a data set with 19,329 individuals who unexpectedly inherited wealth because of the sudden deaths of their legal parents in the period from 1995 to 2001.

Our data set contains economic, financial, and personal information about all individuals in Denmark. We derive data from the following five sources made available through Statistics Denmark:

1. Individual and family data from the official Danish Civil Registration System (CPR Registeret). We use these data to identify all individuals' legal parents. The sample contains the entire Danish population and provides a unique identifying number across individuals, households, and time.

2. Causes of deaths from the Danish Cause-of-Death Register at the Danish National Board of Health (Sundhedsstyrelsen). This data set classifies the cause of death in accordance with international guidelines specified by the World Health Organization's (WHO) International Classification of Diseases (ICD-10) system 4 The source of these data is the official death certificates conveying a medically qualified opinion on the cause of death. We have obtained the cause of death for all Danish citizens who passed away between 1995 and 2007.

3. Employment data from Statistics Denmark's IDA database. Employment data are based on filings from firms and public agencies in the last week of November each year. From these filings we obtain the employment status of all individuals by their CPR number. We use

4 WHO's International Classification of Diseases, ICD-10, is the latest in a series that has its origin in the 1850s. WHO took over the responsibility of ICD at its creation in 1948, and the system is currently used for mortality and morbidity statistics by all member states. 
this data set to identify whether individuals become, and survive as, entrepreneurs. We follow prior literature and define entrepreneurs as self-employed Evans and Jovanovid 1989; Evans and Leighton 1989; Holtz-Eakin, Joulfaian, and Rosen 1994a, 1994b: Blanchflower and Oswald 1998; Fairlie 1999; Quadrini 1999; Gentry and Hubbard 2001; Hurst and Lusardi 2004). Statistics Denmark classifies individuals as self-employed whenever $50 \%$ of their total income originates from entrepreneurial profit. This ensures that we study individuals who are full-time self-employed. In fact, individuals classified as selfemployed in our sample obtain, on average, more than $90 \%$ of their total income from entrepreneurship; most of the remaining residual income is financial income. In addition, the data allow us to check whether individuals' parents are entrepreneurs and thereby to control for differences in entrepreneurial propensities and possible inheritance of businesses.

4. Income and wealth information from the official records at the Danish Tax and Customs Administration (SKAT). SKAT receives this information directly from the relevant sources: Employers supply statements of wages paid to their employees. Financial institutions supply information on their customers' deposits, loans, mortgages, interests (paid or received), security investments, and dividends. SKAT's measure of net wealth includes the most important components of individual wealth (bank deposits, bank loans, property values, mortgages, stocks, mutual funds, and bonds) 5 SKAT's definition of total income equals the sum of labor income, financial income, and entrepreneurial profit. Labor income is wages from paid employment; financial income includes realized capital gains, interests (received or paid), and dividends. Entrepreneurial profit is the pretax profit from self-employment and includes potential gains if the business is sold. The Danish tax code requires that entrepreneurs submit an income statement to the tax authorities. The income statement follows the tax code for corporations, starting with revenues, business expenses, depreciations, and profits. Profits are taxed as personal income, and the tax code allows entrepreneurs to smooth profits and hence taxes through savings inside the firm. Through Statistics Denmark, we have access to entrepreneurial profit as well as the savings inside the firm.

5. Education records from the Danish Ministry of Education. All completed (formal and informal) courses of education are registered on a yearly basis and made available through Statistics Denmark.

5 SKAT does not have information about individuals' holdings of cash outside bank accounts, the value of their cars, their private debt (e.g., debt to private individuals), or other informal wealth holdings (e.g., antiques or stamp collections). 


\subsection{Data construction}

The starting point of our analysis is deceased parents who cause a termination of the household. Terminations of households occur whenever (1) the last living parent dies or (2) both parents die within the same calendar year. In total, we identify 83,602 terminations of households between 1995 and 2001. Panel A in Table 1 shows the distribution across time. From this sample, we identify the cause of death with the purpose of selecting a sample of household terminations resulting from sudden and unexpected death. Panel B details the cause of death based on the WHO's ICD-10 codes.

The identification of relevant ICD-10 codes relies on related medical literature as well as a thorough inspection of the WHO's detailed classification system 6 Thus, among natural deaths, we consider acute myocardial infarction (ICD-10: I22-I23), cardiac arrest (I46), congestive heart failure (I50), stroke (I60-I69), and sudden deaths by unknown causes (R95-R97) as sudden deaths. Among unnatural deaths, traffic accidents (V00-V89) and other accidents and violence (V90-V99, X00-X59, and X86-X90) are unanticipated by the relatives. The latter category excludes suicide or violence by subjects related to the deceased. Panel B tabulates the number of deaths for each type of sudden death, whereas Panel $\mathrm{C}$ shows the total number per year. In total, we identify 12,068 terminations of households due to sudden death(s) from 1995 to 20017

The final step in our sample selection entails linking the deceased to their beneficiaries. On average, each terminated household had 1.60 beneficiaries (i.e., children). This step expands our sample size to 19,329 individuals who experience a wealth windfall.

Table 2 presents summary statistics of our final sample of beneficiaries. As the main focus of the study is identifying individuals who become entrepreneurs after receiving windfall wealth, we split our sample into preshock entrepreneurs and nonentrepreneurs. For all individuals, we report income, wealth, age, gender, education, and marital status for the year prior to their parents' sudden death. Income and wealth are indexed to constant 2000 Danish kroner (DKK). In our sample, $5.8 \%$ of the beneficiaries (1,123 individuals) were already entrepreneurs 8

In keeping with prior literature, Table 2 shows that entrepreneurs have significantly higher income and wealth, are older, and tend to be male.

6 See the WHO's Web page at www.who.int/classifications/icd/en and Andersen and Nielsen 2011) for references to the medical literature.

7 As sudden death, by definition, excludes deaths that are caused by chronic diseases or involve treatment of the deceased prior to death, the classification effectively rules out many of the most common causes of death: For instance, $29 \%$ and $33 \%$ of all deaths are due to neoplasia (mainly cancer) and diseases in the circulatory system, respectively. Among these common causes, only acute myocardial infarction, sudden cardiac arrest, congestive heart failure, and strokes are considered sudden deaths. Thus, only $12.5 \%$ of natural deaths are classified as sudden and unexpected.

8 On average, $8 \%$ of the workforce in Denmark is self-employed. Our beneficiaries are significantly younger than the average individual in the workforce. Becoming self-employed is positively correlated with age, experience, and wealth. We therefore have a lower fraction of self-employed (5.8\%) among beneficiaries when they inherit. 


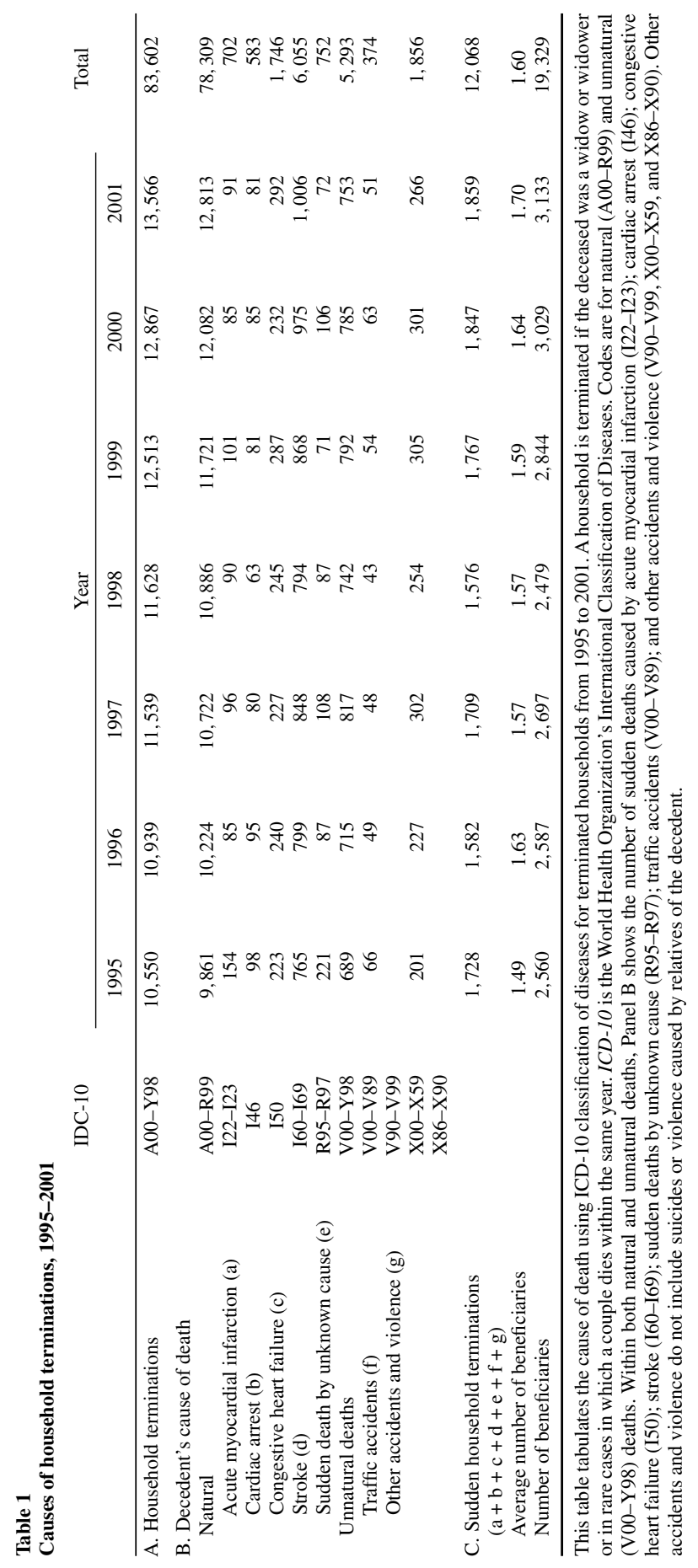

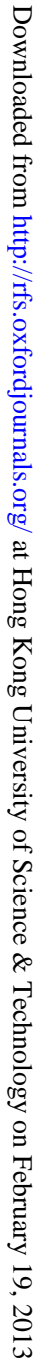


Table 2

Characteristics of preinheritance entrepreneurs versus nonentrepreneurs

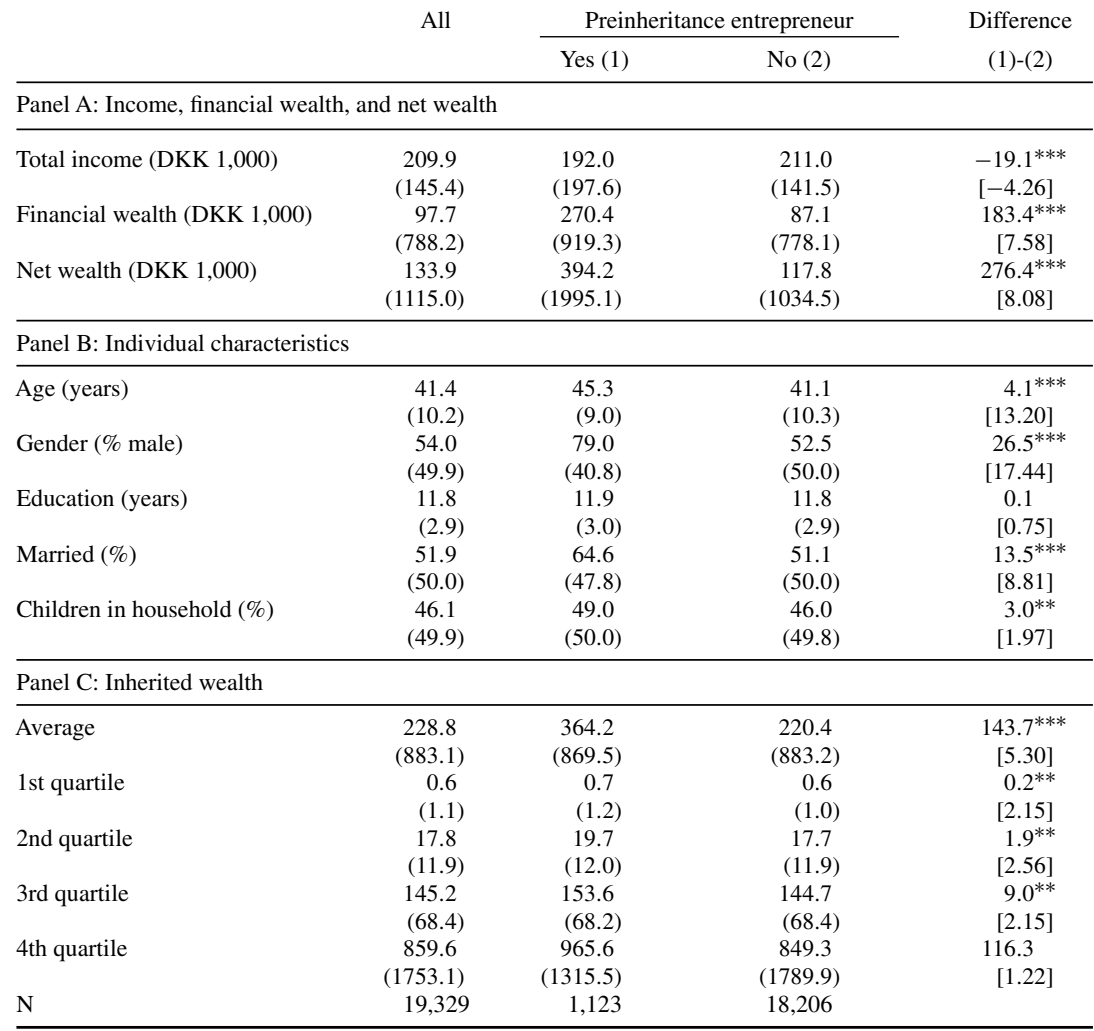

We report descriptive statistics (mean and standard deviation) for all beneficiaries, beneficiaries who are preinheritance entrepreneurs, and nonentrepreneurs, respectively. For each beneficiary, we report total income, financial wealth (bank account, bonds, and stocks), net wealth before inheritance, age, gender, education (years of schooling), marital status, and whether there are children in the household. For each set of descriptive statistics, we also compute the difference in the average characteristics of preinheritance entrepreneurs and nonentrepreneurs and test whether these differences are significantly different from zero. All amounts are in thousand year-2000 DKK. One Euro is equivalent to DKK 7.45. Standard errors are in parentheses, and $t$-statistics are in brackets. $* * *, * *$, and $*$ denote significance at the $1 \%, 5 \%$, and $10 \%$ levels, respectively.

Table 2 also reports the size and distribution of windfall wealth. On average, beneficiaries receive a windfall of DKK 228,800 (EUR 30,700). Inherited wealth is also quite liquid. The deceased parents hold, on average, around half of their wealth in financial assets (bank account, bonds, and stocks). The windfall is economically important, as it is almost twice as large as the average preinheritance net wealth of DKK 133,900 (EUR 17,900). The distribution of inherited wealth has substantial variation. One quarter of the beneficiaries inherit nothing, whereas individuals in the fourth quartile of the distribution of inherited wealth on average receive a windfall of DKK 859,600 (EUR 115,500). Preshock nonentrepreneurs inherit, on average, DKK 220,400 (EUR 29,600), which is equivalent to 1.04 years of total income or 1.87 times the preshock net 
wealth. Thus, the size of windfall appears large enough to provide a sufficient financial cushion for aspiring entrepreneurs to start their own businesses.

\section{Empirical Results}

\subsection{Windfall wealth and the propensity to become entrepreneur}

To test the effect of windfall wealth on entrepreneurial activity, we estimate the difference in entrepreneurial activity around the parent's sudden death. This approach is attractive because it effectively controls for time-invariant individual characteristics that are likely to impact the decision to become and be an entrepreneur. Because our main interest is to understand the start-up decision and performance of new entrepreneurs, we focus solely on individuals who were not self-employed before the event.

The starting point of the analysis is the 18,206 beneficiaries who were nonentrepreneurs prior to receiving windfall wealth (see Table 2). If financial constraints limit firm formation, we expect beneficiaries to exhibit a greater propensity to become entrepreneurs after receiving windfall wealth. To control for expected level of entry absent windfall wealth, we compare the treatment group with a control group of individuals with the same characteristics who do not receive windfall wealth. Our control group is a matched sample of individuals of exactly the same age, gender, and education level and who are from the same preinheritance income and wealth vigintiles (i.e., twenty groups of equal frequency) in the same year as the treated individual. Thus, we apply a one-to-many exact matching procedure, which provides us with a differencein-differences estimate of the average treatment effect of windfall wealth on becoming an entrepreneur?

For some beneficiaries, we cannot identify a match, and as a result, the sample is reduced to 18,009 beneficiaries. Among these, $2.1 \%$ (377 individuals) become self-employed after receiving windfall wealth. In comparison, $0.83 \%$ of the control group becomes an entrepreneur. The difference-in-differences estimate of 1.27 percentage points is significant at the $1 \%$ level.

In Table 3 we run cross-sectional regressions of the propensity to become an entrepreneur among the treated individuals. The dependent variable is the difference between an indicator variable for entry of the treated and the average entry rate for the matched sample (i.e., the difference in differences of the propensity to become an entrepreneur for the treated relative to that of the control group). The variable of interest is inherited wealth measured in million

9 The methodology of difference-in-differences matching follows from Heckman, Ichimura, and Todd 1998). We report consistent results using different matching procedures as presented in Abadie and Imbens (2006) and Hirano and Imben 2004) in the online appendix. We employ our exact one-to-many matching procedure for simplicity. 
Table 3

Exogenous changes in wealth and firm formation

\begin{tabular}{|c|c|c|c|c|}
\hline \multirow{3}{*}{$\begin{array}{l}\text { Independent variable } \\
\text { Model } \\
\text { Sample }\end{array}$} & \multicolumn{4}{|c|}{ Difference-in-differences of the propensity to become entrepreneur } \\
\hline & OLS & OLS & OLS & OLS \\
\hline & All & All & Non-entrepreneurial estates & $\begin{array}{l}\text { Non-entrepreneurial estates } \\
\text { matched on parental wealth }\end{array}$ \\
\hline & (1) & (2) & (3) & (4) \\
\hline Inherited wealth & $\begin{array}{l}0.0097^{* * *} \\
(0.0032)\end{array}$ & $\begin{array}{l}0.0086^{* * *} \\
(0.0032)\end{array}$ & $\begin{array}{l}0.0102^{* * *} \\
(0.0038)\end{array}$ & $\begin{array}{l}0.0137^{* * *} \\
(0.0051)\end{array}$ \\
\hline Inherited wealth squared & $\begin{array}{l}-0.0002^{* * *} \\
(0.0001)\end{array}$ & $\begin{array}{l}-0.0002^{* * *} \\
(0.0001)\end{array}$ & $\begin{array}{l}-0.0005^{* * *} \\
(0.0002)\end{array}$ & $\begin{array}{l}-0.0011^{* *} \\
(0.0005)\end{array}$ \\
\hline Entrepreneurial estate & & $\begin{array}{l}0.0232^{* *} \\
(0.0099)\end{array}$ & & \\
\hline Control variables & Yes & Yes & Yes & Yes \\
\hline Year effects & Yes, fixed & Yes, fixed & Yes, fixed & Yes, fixed \\
\hline $\mathrm{N}$ & 18,009 & 18,009 & 17,539 & 10,675 \\
\hline
\end{tabular}

The dependent variable is the difference between an indicator variable for entry of the treated and the average entry rate for the matched sample (i.e., the difference in differences of the propensity to become an entrepreneur for the treated relative to that of the control group). The control group consists of individuals of the same age, gender, length of education, vigintile of the income distribution, and vigintile of the wealth distribution. In addition to matching on general characteristics, the control group is matched on parental wealth in Column 4 . Inherited wealth is measured in million year-2000 DKK. Inherited wealth squared is the square of inherited wealth. Entrepreneurial estate is an indicator for whether the deceased was an entrepreneur. Control variables include (indicator variables) for changes in marital status and family size. The reported coefficients are marginal effects at the sample means. Standard errors are clustered at the individual level and reported in parentheses. $* * *, * *$, and $*$ denote significance at the $1 \%, 5 \%$, and $10 \%$ levels, respectively.

DKK. Our specifications also include variables to capture changes in individual characteristics and year fixed effects 10

Column 1 of Table 3 shows a positive and significant effect of inherited wealth on the propensity to become an entrepreneur. The effect is significant both economically and statistically. Windfall wealth of one million DKK (EUR 134,200) increases the probability of an individual starting her own business by 0.95 percentage points 11 This figure is relative to a baseline probability of entering into entrepreneurship of $2.1 \%$ for the sample of treated individuals and $0.83 \%$ for the matched sample.

In Columns 2 and 3, we address the critique by Hurst and Lusardi 2004) that relates to inheritance of businesses. In principle, the relationship between windfall wealth and entrepreneurship could be driven by inheritance of entrepreneurial estates. In our sample, $2.6 \%$ of the estates are entrepreneurial. If beneficiaries tend to continue these businesses, the issue appears large enough to explain most of the variation in data. In Column 2, we therefore include an indicator for whether the deceased was an entrepreneur (entrepreneurial estate) and note that the effect of windfall wealth on the propensity to become

10 Our control variables include indicator variables that take the value one if the individual marries, divorces, or has children. We obtain marginal effects of similar magnitude if we alternatively omit control variables, include fixed region-year effects, or include fixed industry-year effects. These results are available in the online appendix.

11 One-standard-deviation increase in inherited wealth yields a marginal effect of 0.86 percentage points, which is close to the reported effect of one million DKK of inherited wealth. 
an entrepreneur remains largely unchanged. In Column 3, we entirely exclude entrepreneurial estates from the sample with little effect on the results.

In Column 4, we include parental wealth among our match characteristics to control for the potential higher propensities to become an entrepreneur in wealthy families. For instance, Hurst and Lusardi 2004) argue that because of strong intergenerational correlation in educational, occupational, savings, and wealth preferences, inherited wealth might capture different entrepreneurial propensities of wealthy families 12 We note that the marginal effect of inherited wealth increases when the control group has identical parental wealth. Thus, the positive effect of windfall wealth on the propensity to become an entrepreneur is not driven by differences in family wealth.

At first glance, the marginal effects of windfalls might appear economically small. Yet, the propensity to become an entrepreneur among treated individuals is more than twice as high as the control group. Thus, windfall wealth allows constrained individuals to become entrepreneurs. This finding is consistent with prior literature Holtz-Eakin. Joulfaian, and Rosen 1994b; Lindh and Ohlsson 1996; Blanchflower and Oswald 1998). Our final sample includes 355 potentially constrained entrepreneurs who formed a business after receiving windfall wealth and excludes 22 beneficiaries who inherit from an entrepreneurial estate and subsequently become entrepreneurs.

\subsection{The performance of the marginal entrepreneur}

Our experiment identifies 355 potentially constrained entrepreneurs. To assess the performance of the constrained entrepreneurs, we analyze their survival rate, entrepreneurial profit, and total income in relation to a matched sample of unconstrained entrepreneurs. The matched sample consists of individuals of the same age, gender, education level, and pre-entrepreneurship income and wealth vigintiles (excluding inheritance) who start a business at the same time as the treated individuals. In case of several matches, we use the matched individual with the closest pre-entrepreneurship income to the treated individual. Thus, we apply a one-to-one exact matching procedure 13 Matching on age, gender, length of education, income, wealth, and entry year is possible because each year, on average, around 25,000 individuals become entrepreneurs. Despite the large control group, we fail to match 51 constrained entrepreneurs, and as a result, the sample is reduced to 30414

12 For instance, Altonii and Dunn 2000) and Charles and Hurst 2003) document strong intergenerational correlations in occupation, education, wealth, and saving preferences.

13 We use the one-to-one exact matching procedure to minimize differences in pre-entrepreneurship income between constrained and unconstrained entrepreneurs. In the online appendix, we report consistent results when using one-to-many matching.

14 The match frequency can be increased by decreasing the list of pre-entrepreneurship characteristics that we match on because we use exact matching. We obtain quantitatively similar results when we match on fewer characteristics or use propensity score matching but also note that the unmatched characteristics of constrained 
Table 4 reports the characteristics of constrained and unconstrained entrepreneurs. The average entrepreneur is 39.5 years old, and $72 \%$ are male. Average annual income in the year before becoming an entrepreneur is DKK 200,700 for constrained, and DKK 207,200 for unconstrained, entrepreneurs. Because of inheritance, net wealth is significantly larger for constrained entrepreneurs. The average constrained entrepreneur possesses wealth of DKK 1,052,500 (EUR 141,300), whereas unconstrained entrepreneurs possess DKK 98,800 (EUR 13,300). This difference is caused by the windfall as we match on preinheritance wealth. Panels B, C, and D of Table 4 show no statistically significant difference between the distribution of individual, geographic, and industry characteristics of constrained and unconstrained entrepreneurs. Thus, without inheritance, constrained and unconstrained entrepreneurs appear identical based on observable characteristics.

Panel A in Table 5 shows average survival rates for constrained entrepreneurs and the matched sample after 1, 2, 3, 4, and 5 years. Entrepreneurship is risky: On average, $64.1 \%$ of the constrained entrepreneurs survive the first year, and only $41.9 \%$ survive the first five years. In comparison, the survival rates for the unconstrained entrepreneurs are significantly higher. After the first year, 75.0\% of the unconstrained entrepreneurs survive, and 50.0\% survive after the first five years. The difference in survival rates between constrained and unconstrained entrepreneurs is significant—both economically and statistically.

The difference in survival rates documented in Panel A in Table 5 might reflect that constrained entrepreneurs are faster at exiting because of efficient stopping rules; have more successful exits; or are taking more risk than the average entrepreneur. In Panel B, we therefore examine entrepreneurial profit, which includes both savings inside the firm and potential gains from successful exits. Panel B of Table 5] documents that unconstrained entrepreneurs have higher entrepreneurial profits than do constrained entrepreneurs. The average difference in entrepreneurial profit varies between DKK 29,600 and 75,100 per year. Moreover, all differences are both economically and statistically significant.

Figure 1 shows the distribution of entrepreneurial profits to examine whether the lower averages are driven by the tails of the distribution. We assign constrained entrepreneurs into bins using the quintile cutoff points from the distribution of entrepreneurial profits for unconstrained entrepreneurs in year 1 . If the distributions are identical, we expect $20 \%$ of the constrained entrepreneurs to be assigned to each bin. Figure 1 shows a different pattern. Constrained entrepreneurs are overrepresented in bin 1 (low income), as 26\% are assigned here, and underrepresented in bin 5 (high income), as only $14 \%$ are assigned here. Among the top $10 \%$ we also find large differences: Only $8 \%$ of the

\footnotetext{
and unconstrained entrepreneurs become less similar. Thus, the presented matching is preferred because it provides a more precise mapping of the characteristics of constrained and unconstrained entrepreneurs. In the online appendix, we conduct a sensitivity analysis, varying matching criteria.
} 
Table 4

Characteristics of constrained and unconstrained entrepreneurs

\begin{tabular}{|c|c|c|c|}
\hline Pre-entrepreneurship characteristics & $\begin{array}{l}\text { Constrained } \\
\text { (1) }\end{array}$ & $\begin{array}{l}\text { Unconstrained } \\
\text { (2) }\end{array}$ & $\begin{array}{l}\text { Difference } \\
\text { (1)-(2) }\end{array}$ \\
\hline \multicolumn{4}{|c|}{ Panel A: Income, financial wealth, and net wealth } \\
\hline Total income (DKK 1,000) & $\begin{array}{r}200.7 \\
(7.7)\end{array}$ & $\begin{array}{r}207.2 \\
(6.3)\end{array}$ & $\begin{array}{l}-6.3 \\
{[-1.26]}\end{array}$ \\
\hline Average income change (DKK 1,000) & $\begin{array}{c}-8.5 \\
(3.3)\end{array}$ & $\begin{array}{c}-6.4 \\
(3.0)\end{array}$ & $\begin{array}{l}-2.2 \\
{[-0.54]}\end{array}$ \\
\hline Financial wealth (DKK 1,000) & $\begin{array}{l}1089.6 \\
(936.9)\end{array}$ & $\begin{array}{l}141.8 \\
(22.2)\end{array}$ & $\begin{array}{c}947.8 \\
{[1.01]}\end{array}$ \\
\hline Net wealth (DKK 1,000) & $\begin{array}{l}1052.5 \\
(945.9)\end{array}$ & $\begin{array}{l}98.8 \\
(51.3)\end{array}$ & $\begin{array}{c}953.7 \\
{[1.02]}\end{array}$ \\
\hline \multicolumn{4}{|l|}{ Panel B: Individual characteristics } \\
\hline Age (years) & $\begin{array}{l}39.5 \\
(0.5)\end{array}$ & $\begin{array}{l}39.5 \\
(0.5)\end{array}$ & - \\
\hline Gender ( $\%$ male) & $\begin{array}{l}71.7 \\
(2.6)\end{array}$ & $\begin{array}{l}71.7 \\
(2.6)\end{array}$ & - \\
\hline Education (years) & $\begin{array}{l}12.0 \\
(0.2)\end{array}$ & $\begin{array}{l}12.0 \\
(0.2)\end{array}$ & - \\
\hline Married (\%) & $\begin{array}{l}54.3 \\
(2.9)\end{array}$ & $\begin{array}{l}51.3 \\
(2.9)\end{array}$ & $\begin{array}{l}3.0 \\
{[0.76]}\end{array}$ \\
\hline Children in household (\%) & $\begin{array}{l}49.7 \\
(2.9) \\
\end{array}$ & $\begin{array}{c}46.7 \\
(2.9) \\
\end{array}$ & $\begin{array}{c}3.0 \\
{[0.83]}\end{array}$ \\
\hline \multicolumn{4}{|l|}{ Panel C: Region of residence } \\
\hline Capital region $(\%)$ & $\begin{array}{l}31.6 \\
(2.7)\end{array}$ & $\begin{array}{l}31.9 \\
(2.7)\end{array}$ & \\
\hline Zealand (\%) & $\begin{array}{l}15.5 \\
(2.1)\end{array}$ & $\begin{array}{l}17.8 \\
(2.2)\end{array}$ & \\
\hline Southern Jutland and Funen (\%) & $\begin{array}{l}20.1 \\
(2.3)\end{array}$ & $\begin{array}{l}19.7 \\
(2.3)\end{array}$ & \\
\hline Central Jutland (\%) & $\begin{array}{l}24.7 \\
(2.5)\end{array}$ & $\begin{array}{l}23.0 \\
(2.4)\end{array}$ & \\
\hline Northern Jutland (\%) & $\begin{array}{l}8.2 \\
(1.6)\end{array}$ & $\begin{array}{l}7.6 \\
(1.5)\end{array}$ & \\
\hline$\chi^{2}$-test & & & 0.75 \\
\hline \multicolumn{4}{|l|}{ Panel D: Industry } \\
\hline Manufacturing (\%) & $\begin{array}{l}7.6 \\
(1.5)\end{array}$ & $\begin{array}{c}7.9 \\
(1.5)\end{array}$ & \\
\hline Construction (\%) & $\begin{array}{l}8.6 \\
(1.6)\end{array}$ & $\begin{array}{l}10.2 \\
(1.7)\end{array}$ & \\
\hline Retail (\%) & $\begin{array}{l}10.5 \\
(1.8)\end{array}$ & $\begin{array}{l}8.6 \\
(1.6)\end{array}$ & \\
\hline Services (\%) & $\begin{array}{l}50.0 \\
(2.9)\end{array}$ & $\begin{array}{l}48.7 \\
(2.9)\end{array}$ & \\
\hline Transportation (\%) & $\begin{array}{l}4.9 \\
(1.2)\end{array}$ & $\begin{array}{l}4.9 \\
(1.2)\end{array}$ & \\
\hline Unknown (\%) & $\begin{array}{l}18.4 \\
(2.2)\end{array}$ & $\begin{array}{l}19.7 \\
(2.3)\end{array}$ & \\
\hline$\chi^{2}-$ test & & & 1.27 \\
\hline $\mathrm{N}$ & 304 & 304 & \\
\hline
\end{tabular}

We report descriptive statistics (mean and standard error) for constrained and unconstrained entrepreneurs. Constrained entrepreneurs are individuals who become entrepreneurs after receiving windfall wealth because of the sudden death of their parents. The matched sample of unconstrained entrepreneurs consists of individuals who were able to start their businesses without receiving windfall wealth. Unconstrained entrepreneurs have the same age, gender, and length of education; are from the same vigintiles of the income and wealth distributions; and started their businesses at the same time as the constrained entrepreneurs. In Panel A, we report total income, average income change in the three prior years, financial wealth (bank account, bonds, and stocks), and net wealth after inheritance. Panel B reports individual characteristics: age, gender, education (years of schooling), marital status, and whether there are children in the household. Panel C reports the region of residence, whereas Panel D reports the main industry. For each set of descriptive statistics, we also compute the difference in the average characteristics of constrained and unconstrained entrepreneurs and test whether these differences are significantly different from zero. All amounts are in thousand year-2000 DKK. Standard errors are in parentheses, and $t$-statistics are in brackets. ***, **, and * denote significance at the $1 \%, 5 \%$, and $10 \%$ levels, respectively. 
Table 5

Differences in firm survival rates, entrepreneurial profits, and total income

\begin{tabular}{|c|c|c|c|c|c|c|}
\hline & Year 0 & Year 1 & Year 2 & Year 3 & Year 4 & Year 5 \\
\hline \multicolumn{7}{|l|}{ Panel A: Survival rates } \\
\hline $\begin{array}{l}\text { Constrained entrepreneurs } \\
\text { Unconstrained entrepreneurs } \\
\text { Difference }\end{array}$ & $\begin{array}{l}1.000 \\
1.000 \\
-\end{array}$ & $\begin{array}{l}0.641 \\
0.750 \\
-0.109^{* * *} \\
{[-2.90]}\end{array}$ & $\begin{array}{r}0.580 \\
0.637 \\
-0.057 \\
{[-1.49]}\end{array}$ & $\begin{array}{r}0.535 \\
0.588 \\
-0.053 \\
{[-1.34]}\end{array}$ & $\begin{array}{c}0.457 \\
0.530 \\
-0.073^{*} \\
{[-1.92]}\end{array}$ & $\begin{array}{c}0.419 \\
0.500 \\
-0.081^{* *} \\
{[-1.98]}\end{array}$ \\
\hline $\mathrm{N}$ & 304 & 304 & 304 & 304 & 304 & 304 \\
\hline \multicolumn{7}{|l|}{ Panel B: Entrepreneurial profits } \\
\hline $\begin{array}{l}\text { Constrained entrepreneurs } \\
\text { Unconstrained entrepreneurs } \\
\text { Difference }\end{array}$ & $\begin{array}{l}101.3 \\
128.8 \\
-27.5^{*} \\
{[-1.84]}\end{array}$ & $\begin{array}{l}141.7 \\
182.7 \\
-41.0^{* *} \\
{[-1.98]}\end{array}$ & $\begin{array}{l}121.2 \\
184.6 \\
-63.4^{* * *} \\
{[-3.03]}\end{array}$ & $\begin{array}{l}110.6 \\
183.0 \\
-72.4^{* * * *} \\
{[-3.11]}\end{array}$ & $\begin{array}{l}104.0 \\
179.1 \\
-75.1^{* * *} \\
{[-3.21]}\end{array}$ & $\begin{array}{c}106.3 \\
155.2 \\
-48.9^{* *} \\
{[-2.16]}\end{array}$ \\
\hline $\mathrm{N}$ & 304 & 304 & 304 & 304 & 304 & 304 \\
\hline \multicolumn{7}{|c|}{ Panel C: Entrepreneurial profits among surviving firms } \\
\hline $\begin{array}{l}\text { Constrained entrepreneurs } \\
\text { Unconstrained entrepreneurs } \\
\text { Difference }\end{array}$ & $\begin{array}{l}101.3 \\
128.8 \\
-27.5^{*} \\
{[-1.84]}\end{array}$ & $\begin{array}{l}170.7 \\
196.9 \\
-26.2 \\
{[-1.31]}\end{array}$ & $\begin{array}{l}165.7 \\
235.8 \\
-70.1^{* * *} \\
{[-3.03]}\end{array}$ & $\begin{array}{l}174.0 \\
243.3 \\
-69.3^{* *} \\
{[-2.24]}\end{array}$ & $\begin{array}{l}198.4 \\
251.1 \\
-52.7^{*} \\
{[-1.70]}\end{array}$ & $\begin{array}{l}244.3 \\
263.8 \\
-19.5 \\
{[-0.54]}\end{array}$ \\
\hline $\mathrm{N}$ & 304 & 227 & 202 & 169 & 132 & 104 \\
\hline \multicolumn{7}{|l|}{ Panel D: Retained earnings } \\
\hline $\begin{array}{l}\text { Constrained entrepreneurs } \\
\text { Unconstrained entrepreneurs } \\
\text { Difference }\end{array}$ & $\begin{array}{c}9.6 \\
22.8 \\
-13.1^{* *} \\
{[-2.06]}\end{array}$ & $\begin{array}{l}11.8 \\
25.3 \\
-13.5 \\
{[-1.16]}\end{array}$ & $\begin{array}{c}10.3 \\
11.6 \\
-1.3 \\
{[-0.12]}\end{array}$ & $\begin{array}{l}9.9 \\
7.6 \\
2.3 \\
{[0.18]}\end{array}$ & $\begin{array}{l}14.3 \\
23.0 \\
-8.8 \\
{[-0.73]}\end{array}$ & $\begin{array}{c}12.2 \\
16.5 \\
-4.4 \\
{[-0.44]}\end{array}$ \\
\hline $\mathrm{N}$ & 304 & 304 & 304 & 304 & 304 & 304 \\
\hline \multicolumn{7}{|l|}{ Panel E: Total income } \\
\hline $\begin{array}{l}\text { Constrained entrepreneurs } \\
\text { Unconstrained entrepreneurs } \\
\text { Difference }\end{array}$ & $\begin{array}{l}158.9 \\
172.4 \\
-13.5 \\
{[-1.39]}\end{array}$ & $\begin{array}{l}156.9 \\
180.5 \\
-23.6 \\
{[-1.63]}\end{array}$ & $\begin{array}{l}167.7 \\
202.5 \\
-34.8^{* * *} \\
{[-2.69]}\end{array}$ & $\begin{array}{l}177.7 \\
216.5 \\
-38.8^{* * *} \\
{[-3.03]}\end{array}$ & $\begin{array}{l}177.2 \\
206.9 \\
-29.7^{* *} \\
{[-2.40]}\end{array}$ & $\begin{array}{l}194.1 \\
204.5 \\
-10.4 \\
{[-0.85]}\end{array}$ \\
\hline $\mathrm{N}$ & 304 & 304 & 304 & 304 & 304 & 304 \\
\hline
\end{tabular}

This table reports survival rates, entrepreneurial profits, and total income for constrained individuals who become self-employed after receiving windfall wealth. The matched sample of unconstrained entrepreneurs consists of individuals who were able to start their businesses without receiving windfall wealth. Unconstrained entrepreneurs have the same age, gender, and length of education; are from the same vigintiles of the income and wealth distributions; and started their businesses at the same time as the constrained entrepreneurs. Panel A reports survival rates; Panel B reports entrepreneurial profits; Panel C reports entrepreneurial profits for surviving firms; Panel D reports retained earnings; and Panel E reports total income. Difference is the difference in income between constrained and unconstrained entrepreneurs. Profits and income are measured in 1,000 DKK. $t$-statistics are in brackets. $* * *, * *$, and $*$ denote significance at the $1 \%, 5 \%$, and $10 \%$ levels, respectively.

constrained entrepreneurs are assigned here, and their average entrepreneurial profit equals DKK 662,000, whereas that of unconstrained entrepreneurs equals DKK 834,000. The difference in the distribution of entrepreneurial profit shows that the lower performance is not driven by outliers.

Panel $\mathrm{C}$ of Table 5 shows that differences in entrepreneurial profit persist when the sample is reduced to surviving entrepreneurs (both treatment and control have to survive). Again we find that unconstrained entrepreneurs have higher income from entrepreneurship. The differences are large and significant 


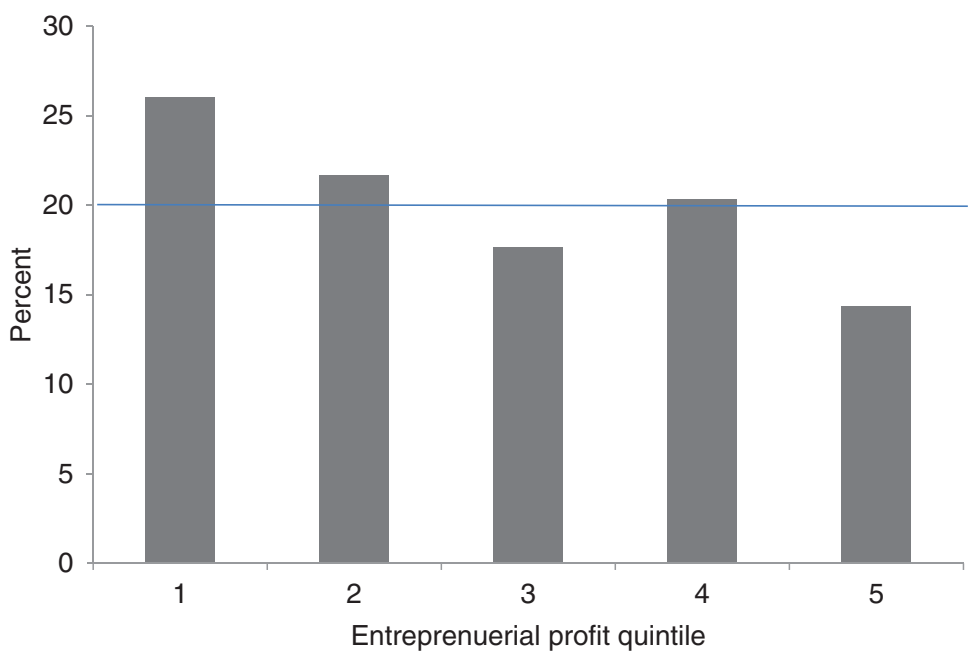

Figure 1

Relative distribution of entrepreneurial profit for constrained entrepreneurs in year 1

This figure reports the distribution of entrepreneurial profit for constrained entrepreneurs relative to the distribution for unconstrained entrepreneurs in year 1. Constrained entrepreneurs are assigned into bins using the quintile cutoff points from the distribution of entrepreneurial profits for unconstrained entrepreneurs in year 1 . Quintile 1 (5) represents the lowest (highest) entrepreneurial profits. If the distributions are identical, we expect $20 \%$ of the constrained entrepreneurs to be assigned to each bin.

in the initial phase. By the end of the fifth year, when only $41.9 \%$ of the constrained entrepreneurs have survived, the difference in profit is smaller.

Although entrepreneurial profit includes retained earnings, the tax code makes it advantageous to retain earnings inside the firm. Retained earnings are only partly taxed in the income year and partly taxed in the year of extraction. Postponing income taxes by retaining earnings is particularly valuable in years with high income because of progressive taxation. As the ability to benefit from this tax rule is likely to be increasing with wealth, we examine in Panel D whether constrained entrepreneurs retain more entrepreneurial profit than do unconstrained entrepreneurs. Panel D shows that, on the contrary, unconstrained entrepreneurs retain more earnings than do constrained entrepreneurs.

In Panel E of Table 5 we report the total income for constrained and unconstrained entrepreneurs. The assessment of total income helps ascertain whether lower survival rates of constrained entrepreneurs are driven by constrained entrepreneurs being more effective at imposing efficient stopping rules. If constrained entrepreneurs are more effective at imposing efficient stopping rules, we expect them to have higher total income, either because they return to paid employment or because they stop loss-making businesses earlier. If this is the case, differences in total income will be smaller. We further expect the differences in total income to be smaller because total income includes 
cost of external financing (interest payments) and excludes opportunity cost of capital for self-financed entrepreneurs. Constrained entrepreneurs possess more wealth than unconstrained entrepreneurs and are therefore more likely to self-finance their business. Thus, the inclusion of financial income will bias against finding differences in total income.

Panel E of Table 5 reports the difference in total income between constrained and unconstrained entrepreneurs. After their first year as entrepreneurs, constrained entrepreneurs have DKK 23,600 lower total income than do unconstrained entrepreneurs. The difference is equivalent to $11.8 \%$ of the preentrepreneurship level. In years 2 and 3, the difference increases to DKK 34,800 and 38,800 , respectively. Both differences are statistically significant at the $1 \%$ level. In years 4 and 5, the difference in total income declines to DKK 29,700 and 10,400 , respectively.

Panel A in Figure 2 provides a comparison of total income among constrained and unconstrained entrepreneurs, whereas Panel B compares the total income for individuals who receive windfalls but stay in employment to a matched sample of similar individuals. On average, constrained entrepreneurs earn less from self-employment. The area between the two lines provides a graphical illustration of the relative underperformance of constrained entrepreneurs. Interestingly, Panel B shows no effect on total income for individuals who received windfall wealth but stayed in paid employment.

The lower income from entrepreneurship is hardly surprising, as prior literature documents lower earnings from self-employment. Using survey data on U.S. individuals, Hamilton 2000 compares the wage differential between self-employed and paid employees. He finds that the self-employed earn a significantly smaller stream of future earnings. This finding suggests that entrepreneurs are willing to sacrifice substantial earnings in exchange for nonpecuniary benefits, such as the value of "being your own boss." The lower income might also be attributed to the ability to underreport income among the self-employed. Estimates of underreporting range from $18 \%$ to $57 \%$ in the United States Slemrod 2007; Sarada 2010, whereas average underreporting is $14.8 \%$ in Denmark among the self-employed who are randomly selected for a tax audit Kleven et al. 2011). We note that although the magnitude of underreported income can explain part of the drop in income for individuals who become self-employed, it cannot explain differences in earnings between constrained and unconstrained entrepreneurs, unless constrained entrepreneurs are more prone to evade taxes. We consider this possibility in Section 3

\subsection{Determinants of the performance of the marginal entrepreneur}

Although the comparison between constrained and unconstrained entrepreneurs successfully controls for time-invariant individual heterogeneity captured by our match characteristics, it is still interesting to examine the marginal effect of individual characteristics. In Table 6 therefore, we run regressions of 

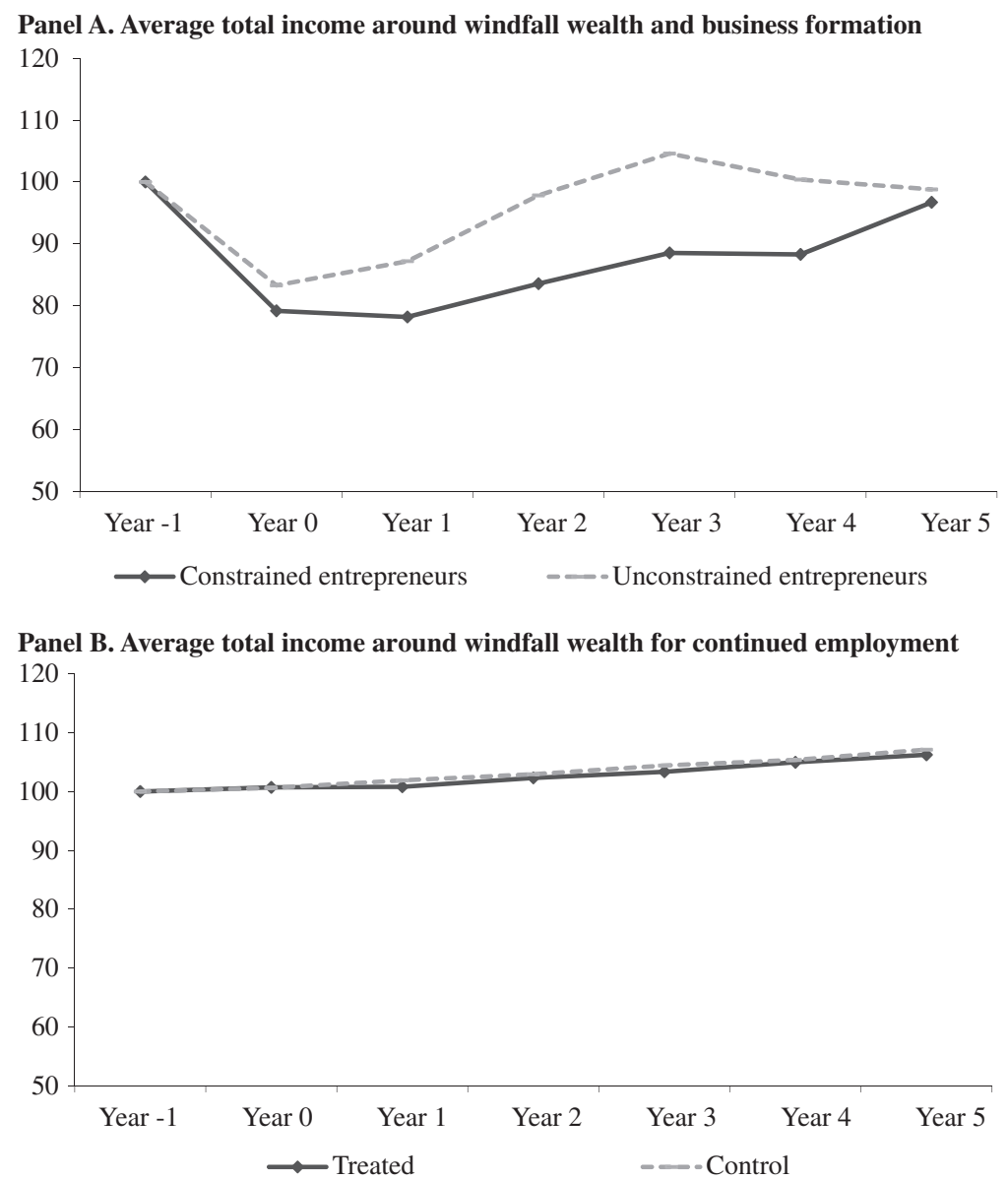

Figure 2

Total income around windfall wealth

Panel A plots total income for constrained and unconstrained entrepreneurs. Constrained entrepreneurs are individuals who become self-employed after receiving a windfall wealth. Unconstrained entrepreneurs are a matched sample of individuals who were able to start their businesses without receiving windfall wealth. Unconstrained entrepreneurs have the same age, gender, and length of education; are from the same vigintiles of the income and (preinheritance) wealth distributions; and started their businesses at the same time as the constrained entrepreneurs. Panel B plots total income for continued employment among individuals who receive windfall wealth but continue with their existing jobs (Treated). The control group consist of a matched sample of similar individuals. Total income is indexed to the pre-entrepreneurship and preinheritance level (year $-1=100)$.

entrepreneurial outcomes, while controlling for individual characteristics, and report the marginal effects.

In Column 1 of Table 6 the dependent variable is business closure, which takes the value one if the business is closed, either as a failure or a success. Our variable of interest is an indicator taking the value one if the entrepreneur 


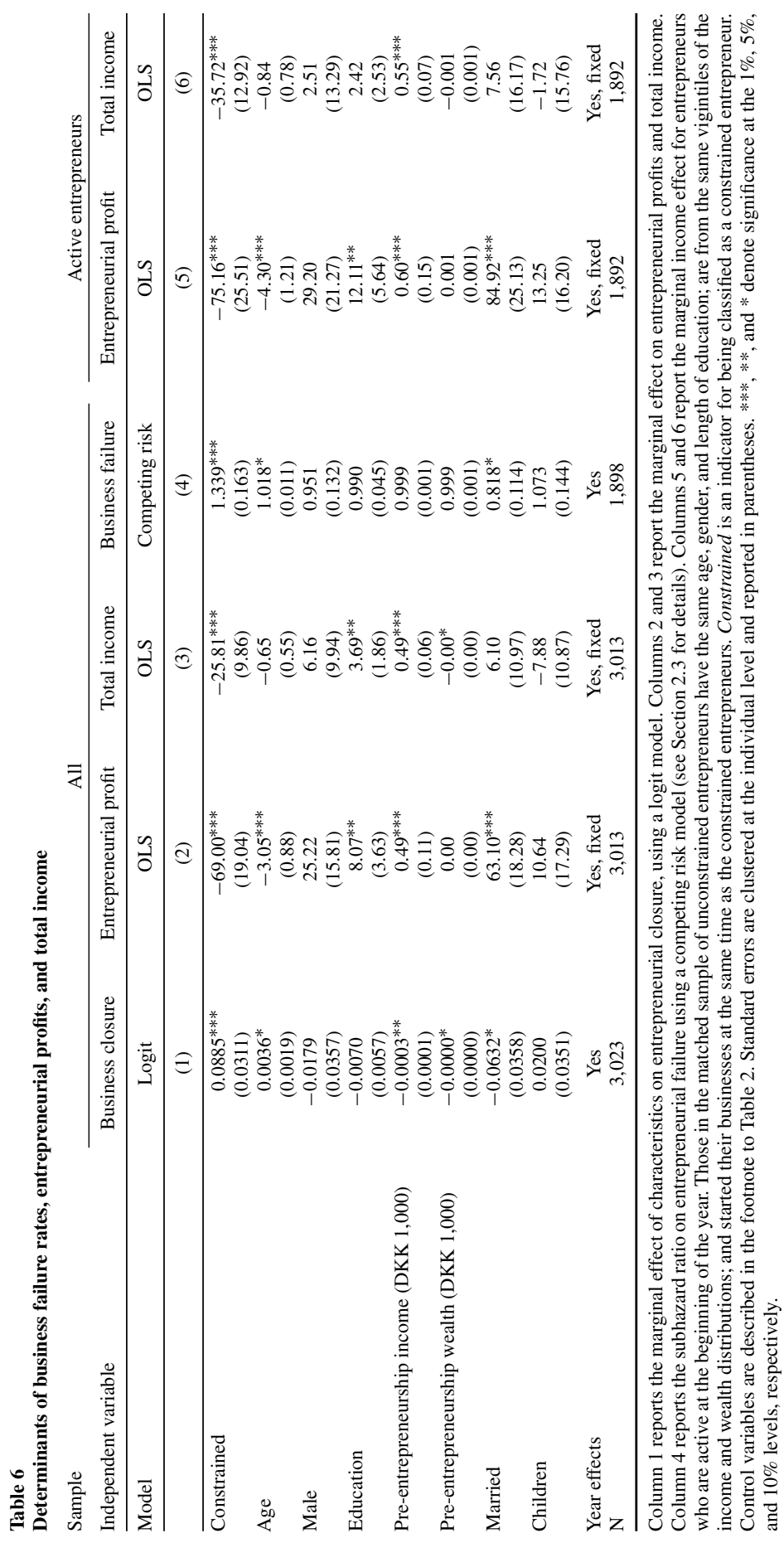

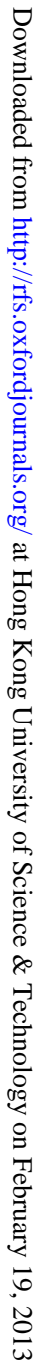


is constrained. By construction there is no time variation in constrained. We therefore use the pooled data over the five-year window to evaluate performance and estimate the relationship in a logit model with clustered standard errors at the individual level. We include age, gender, education, pre-entrepreneurship income, preinheritance, and pre-entrepreneurship wealth, as well as indicator variables equal to one if the entrepreneur is married or has children, and year effects. The results reveal that constrained entrepreneurs, on average, are 8.85 percentage points more likely to close their businesses. This difference is significant at the $1 \%$ level.

Exits capture both failure through closure of the business or success through selling the business. To examine that the lower survival rates of constrained entrepreneurs are driven by failure rather than success, we follow Fine and Gray 1999 ) and estimate a competing risk model. Success through business sales is not directly observed in our data, but profits from sales are included in the entrepreneurial profit recorded by the tax authorities. We therefore characterize an exit as success if a large positive entrepreneurial profit is reported in the year of exit and an exit as failure if the entrepreneurial profit is low. We use a conservative characterization of success and set the cutoff level to DKK 100,000 . In accordance with this conservative classification, $16.5 \%$ of all exits are classified as successful outcomes (14.8\% for constrained entrepreneurs and $18.4 \%$ for unconstrained entrepreneurs). Column 4 of Table 6 reports the results from the competing risk model. We estimate a subhazard rate of failures of 1.34 for constrained entrepreneurs, which is significant at the $1 \%$ level 15 Thus, constrained entrepreneurs fail much faster than do unconstrained entrepreneurs.

In Columns 2 and 3, we analyze the income from entrepreneurship. Again we use the pooled data from the five-year window, while controlling for individuals characteristics and year-fixed effects. We estimate the relationship using a linear regression model, where standard errors are clustered at the individual level. Column 2 shows that constrained entrepreneurs, on average, earn DKK 69,000 less per year in entrepreneurial profits over the five years. These differences are relative to a pre-entrepreneurship total income of DKK 200,700 and are, thus, economically significant. Column 2 shows that constrained entrepreneurs, on average, also have DKK 25,810 lower total income per year than do unconstrained entrepreneurs in the five years after business formation. We also note that the coefficients on the control variables are consistent with prior literature: Entrepreneurial profit is increasing in education and pre-entrepreneurship total income and is decreasing in age.

To nuance the story, in alternative specifications we also examine the difference in entrepreneurial profits and total income between constrained and

15 Our definition classifies 54 out of 328 exits as successes. Using different cutoff levels to define "success" changes the estimated subhazard rate for constrained entrepreneurs very little. We obtain subhazard rates of $1.338,1.288$, and 1.284 when we alternatively define success as exits with entrepreneurial profit above DKK 50,000, DKK 250,000, and DKK 500,000, respectively. 
unconstrained entrepreneurs. We find that the underperformance of constrained entrepreneurs is higher for individuals with higher pre-entry income and longer education. In general, performance is increasing in both income and education for both constrained and unconstrained entrepreneurs. Yet, because the increase is larger for the latter group, the underperformance of constrained entrepreneurs is increasing in income and education. We also find the underperformance to be stronger for individuals who do not stay with their industry (measured at the four-digit industry level). This evidence suggests that underperformance is concentrated among individuals who, despite having longer education and higher income, could not obtain financing to undertake projects outside the industry in which they were employed.

One concern with the results in Columns 2 and 3 is that the underperformance could be driven by exiting entrepreneurs. The samples in Columns 5 and 6 therefore only contain entrepreneurs who are active at the beginning of each year and exclude failed entrepreneurs in the following years. Again, we find significantly lower entrepreneurial profits and total income among the constrained entrepreneurs. On average, constrained entrepreneurs have DKK 75,200 lower entrepreneurial profits when the sample is restricted to active businesses. If we focus on total income, the average difference is DKK 35,700 per year.

In summary, constrained entrepreneurs appear to have significantly poorer outcomes than do unconstrained entrepreneurs. They have lower survival rates and earn significantly lower profits from their businesses. The poor performance is consistent with our hypothesis that these individuals face constraints to entrepreneurship because of their low quality rather than their access to financing.

\section{Treatment versus Wealth Effects}

Although the evidence in Tables 5 and 6 supports the hypothesis that entrepreneurs face financial constraints because of low entrepreneurial quality, our experiment shows that entry into entrepreneurship is positively affected by inherited wealth. The treatment effect might therefore be confounded by a wealth effect that potentially can explain the results. For instance, wealth might positively affect risk taking, investments, consumption through the firm, savings inside the firm, and tax avoidance and, thereby, possibly explain the observed performance measured through profits and income. Alternatively, entrepreneurship can be interpreted as a luxury good that only wealthy individuals can afford.

The idea that wealth can affect entrepreneurial outcomes is not new. For instance, Hvide and Møen 2010) show that entrepreneurs' start-up performances are a function of their wealth. They find that the relationship between start-up performance, as measured by profitability on assets, and wealth increases in the first three wealth quartiles but drops in the top wealth 
quartile. Nanda 2008) also provides evidence of higher failure rates among the most wealthy entrepreneurs, which suggests that the spike in entry at the top end of the wealth distribution is driven by low-ability entrepreneurs who can afford to start weaker firms because they do not face the discipline of external finance.

To assess whether our interpretation of the evidence is consistent with a treatment effect and not driven by a confounding wealth effect, we perform several additional tests.

\subsection{Controlling for inherited wealth}

We start the analysis and discussion of treatment versus wealth effects by examining whether inherited wealth directly affects outcomes. In accordance with the alternative interpretation of the uncovered evidence as being driven by a confounding wealth effect, we expect inherited wealth to correlate negatively with outcomes. We therefore include inherited wealth as a control variable in our empirical specifications.

Column 1 of Table 7 shows a positive effect of inherited wealth on failure rates and negative effects on entrepreneurial profits and total income, but all effects are statistically insignificant. More importantly, the estimated coefficients on the indicator for constrained entrepreneurs are of similar magnitude when compared to the estimates in Columns 1, 2, and 3 in Table 6 There appears to be no systematic relationship between inherited wealth and outcomes, and the inclusion of windfall wealth does not impact the estimated underperformance of constrained entrepreneurs.

Another way to address whether the treatment effect is confounded by a wealth effect is to revise our match characteristics. Rather than matching on preinheritance wealth, we match on the postinheritance level. If our results are driven by the confounding wealth effect, we should expect to see no difference in performance between constrained and unconstrained entrepreneurs when we match on postinheritance wealth. Column 2 in Table 7 reports the results. The findings in Column 2 show that large differences in performance between the constrained and unconstrained entrepreneurs are not driven by a general effect of wealth on firm performance.

\subsection{Controlling for parental wealth}

Differences in parental wealth might also influence aspiring entrepreneurs' ability to form a successful business. In particular, we find that beneficiaries' propensity to become self-employed is increasing in inherited wealth and, thus, parental wealth. Differences in parental wealth might explain the documented underperformance if individuals from wealthy families are less motivated to exert effort. Although including inherited wealth and matching on the postinheritance wealth level partly addresses this issue, one might still be concerned with the possibility of family wealth influencing the results. In Column 3 of Table 7 we therefore report the performance of constrained 
Table 7

Treatment versus wealth effect

\begin{tabular}{|c|c|c|c|c|c|}
\hline \multirow[b]{2}{*}{ Matching criteria on wealth } & \multicolumn{4}{|c|}{ Treatment test } & Placebo test \\
\hline & $\begin{array}{l}\text { Pre-inheritance } \\
\text { wealth }\end{array}$ & $\begin{array}{l}\text { Post- } \\
\text { inheritance } \\
\text { wealth }\end{array}$ & Parental wealth & $\begin{array}{l}\text { Pre-inheritance } \\
\text { wealth }\end{array}$ & $\begin{array}{l}\text { Pre-inheritance } \\
\text { wealth }\end{array}$ \\
\hline
\end{tabular}

\begin{tabular}{|c|c|c|c|c|c|}
\hline & (1) & (2) & (3) & (4) & (5) \\
\hline \multicolumn{6}{|l|}{ Panel A: Business closure } \\
\hline Constrained & $\begin{array}{l}0.0841^{* *} \\
(0.0335)\end{array}$ & $\begin{array}{l}0.0748^{* * *} \\
(0.0314)\end{array}$ & $\begin{array}{c}0.0604 \\
(0.0463)\end{array}$ & $\begin{array}{r}0.1146^{*} \\
(0.0661)\end{array}$ & \\
\hline Inherited wealth & $\begin{array}{c}0.0185 \\
(0.0552)\end{array}$ & & & & \\
\hline $\begin{array}{l}\text { Constrained * Treatment of } \\
\text { unconstrained }\end{array}$ & & & & $\begin{array}{c}0.0189 \\
(0.0571)\end{array}$ & \\
\hline Treatment of unconstrained & & & & & $\begin{array}{l}-0.0604^{* *} \\
(0.0304)\end{array}$ \\
\hline Control variables & Yes & Yes & Yes & Yes & Yes \\
\hline Year effects & Yes & Yes & Yes & No & Yes \\
\hline $\mathrm{N}$ & 3,023 & 3,017 & 1,508 & 1,373 & 3,128 \\
\hline \multicolumn{6}{|l|}{ Panel B: Entrepreneurial profit } \\
\hline Constrained & $\begin{array}{l}-61.72^{* * *} \\
(19.17)\end{array}$ & $\begin{array}{l}65.67^{* * *} \\
(19.17)\end{array}$ & $\begin{array}{l}-55.64^{* *} \\
(26.97)\end{array}$ & $\begin{array}{l}-81.23^{* * * *} \\
(28.08)\end{array}$ & \\
\hline Inherited wealth & $\begin{array}{c}-30.67 \\
(19.98)\end{array}$ & & & & \\
\hline $\begin{array}{l}\text { Constrained * Treatment of } \\
\text { unconstrained }\end{array}$ & & & & $\begin{array}{r}-11.16 \\
(24.48)\end{array}$ & \\
\hline Treatment of unconstrained & & & & & $\begin{array}{c}10.31 \\
(20.05)\end{array}$ \\
\hline Control variables & Yes & Yes & Yes & Yes & Yes \\
\hline Year-fixed effects & Yes & Yes & Yes & No & Yes \\
\hline $\mathrm{N}$ & 3,013 & 3,006 & 1,501 & 1,364 & 3,128 \\
\hline \multicolumn{6}{|l|}{ Panel C: Total income } \\
\hline Constrained & $\begin{array}{l}-22.49^{* * *} \\
(10.24)\end{array}$ & $\begin{array}{l}-28.89^{* * * *} \\
(10.89)\end{array}$ & $\begin{array}{l}-47.13^{* * * *} \\
(15.74)\end{array}$ & $\begin{array}{c}-19.77 \\
(20.20)\end{array}$ & \\
\hline Inherited wealth & $\begin{array}{r}-13.67 \\
(11.83)\end{array}$ & & & & \\
\hline $\begin{array}{l}\text { Constrained } * \text { Treatment of } \\
\text { unconstrained }\end{array}$ & & & & $\begin{array}{c}3.22 \\
(18.97)\end{array}$ & \\
\hline Treatment of unconstrained & & & & & $\begin{array}{l}-5.21 \\
(13.09)\end{array}$ \\
\hline Control variables & Yes & Yes & Yes & Yes & Yes \\
\hline Year-fixed effects & Yes & Yes & Yes & No & Yes \\
\hline $\mathrm{N}$ & 3,013 & 3,006 & 1,501 & 1,364 & 3,128 \\
\hline
\end{tabular}

Columns 1 to 4 report the differences in business closure, entrepreneurial profit, and total income between constrained and unconstrained entrepreneurs. Constrained entrepreneurs are individuals who become self-employed after receiving windfall wealth. Unconstrained entrepreneurs are a matched sample of individuals who were able to start their businesses without receiving windfall wealth. Unconstrained entrepreneurs have the same age, gender, and length of education; are from the same vigintiles of the income and wealth distributions; and started their businesses at the same time as the constrained entrepreneurs. The main exception is Column 4, in which the matched sample consists of unconstrained entrepreneurs who receive windfall wealth in years 1 to 3 after business formation. Unconstrained entrepreneurs in Column 4 have the same gender and length of education; are from the same vigintiles of the income and wealth distributions; and started their businesses at the same time as the constrained entrepreneurs. Column 5 reports differences in business closure, entrepreneurial profits, and total income from a placebo test of inherited wealth among unconstrained entrepreneurs who suddenly inherit in years 1 to 3 after business formation. Columns 1,4 , and 5 use preinheritance wealth to form the matched sample. Column 2 uses postinheritance wealth instead of preinheritance wealth to form the matched sample of unconstrained entrepreneurs. Column 3 uses parental wealth instead of individual wealth to form the matched sample of unconstrained entrepreneurs. Regressions in Panels A, B, and C are specified as Columns 1, 2, and 3 in Table 6 respectively. Constrained is an indicator for being classified as a constrained entrepreneur. Treatment of unconstrained is an indicator equal to one after the treatment of unconstrained entrepreneurs with windfall wealth. Inherited wealth is in million DKK. Standard errors are clustered at the individual level and reported in parentheses. ***, **, and * denote significance at the $1 \%, 5 \%$, and $10 \%$ levels, respectively. 
entrepreneurs in relation to a matched sample of unconstrained entrepreneurs from equally wealthy families. Thus, rather than matching on preinheritance wealth, we match on parental wealth.

From Column 3 of Table 7 we observe economic underperformance of constrained entrepreneurs, consistent with the main results. We also note that the differences in performance are slightly smaller than the main results when we match on parental wealth. We conjecture that this result is driven by parental financing of offspring entrepreneurs among the control sample. If parents desire to provide financial support to offspring, they are likely to finance projects that could not obtain financing from financial intermediaries.

\subsection{Using unconstrained entrepreneurs who receive windfall wealth as control group}

Our final tests focus on using existing entrepreneurs whose parents die suddenly in years 1 to 3 after business formation as counterfactual in our experiment. Existing entrepreneurs are unconstrained in the sense that they started their businesses before receiving windfall wealth. As sudden deaths are unanticipated, we can use the exogenous timing of the windfall to unconstrained entrepreneurs to directly test whether our results are confounded by a wealth effect. If windfall wealth affects entrepreneurial outcomes, the performance of unconstrained entrepreneurs will be negatively affected after they inherit wealth. Hence, under the alternative hypothesis, we expect the differences in performance to be larger before unconstrained entrepreneurs inherit.

We form a control sample of unconstrained entrepreneurs who start a business at the same time but inherit in years 1 to 3 after business formation. We match on education level, gender, pre-entrepreneurship income, and wealth (excluding inheritance). We relax the exact matching on age because the sample of treated unconstrained entrepreneurs is relatively small 16 With these matching criteria we can successfully match 140 constrained entrepreneurs to unconstrained entrepreneurs, and except for age, no statistical difference exists between the characteristics of the two groups. On average, constrained entrepreneurs are 39.9 years old, and unconstrained entrepreneurs are 41.8 years old. Although this difference is statistically significant at the $10 \%$ level, we note that this difference will bias against finding differences in performance, as age in general correlates negatively with entrepreneurial performance (see Table 6).

Results in Column 4 of Table 7 provide evidence in favor of our hypothesis. Unconstrained entrepreneurs are $11.5 \%$ more likely to survive than are constrained entrepreneurs. After unconstrained entrepreneurs receive windfall wealth, the difference in survival rates increases by 1.9 percentage points, as

16 Table 2 shows that our sample of beneficiaries includes 1,123 individuals who are entrepreneurs before they receive windfall wealth. As we require that the windfall occurs shortly after business formation, the number of unconstrained entrepreneurs who receive windfall wealth is even lower, which forces us to exclude age as a matching characteristic. 
indicated by the interaction term (Constrained $*$ Treatment of unconstrained entrepreneurs). We find similar results for entrepreneurial profit. Before unconstrained entrepreneurs inherit wealth, their entrepreneurial profit is DKK 90,900 higher than that of constrained entrepreneurs, and after inheritance, the difference increases to DKK 99,700.

Finally, we perform a placebo test to examine whether inherited wealth has an adverse effect on performance among our sample of unconstrained entrepreneurs who inherit in years 1 to 3 after business formation. If wealth affects outcomes through the channels previously discussed, we expect performance to decline once unconstrained entrepreneurs receive windfall wealth.

Column 5 in Table 7 reports the results from the placebo test (treatment of unconstrained entrepreneurs) of the effect of inherited wealth on outcomes for unconstrained entrepreneurs as compared with a matched sample of unconstrained entrepreneurs who do not receive windfall wealth. We note that unconstrained entrepreneurs who receive windfalls survive slightly longer than does the matched sample. This result is consistent with the findings of HoltzEakin, Joulfaian, and Rosen 1994b), who analyze the effect of inherited wealth on performance of existing entrepreneurs two to three years after receiving an inheritance. When we inspect the underlying survival rates, we note that the difference tends to decline over time. Thus, windfalls to existing entrepreneurs postpone exit but have little long-term effect. We conclude that the placebo test bolsters our hypothesis that the lower survival rates, profits, and income of constrained entrepreneurs are driven by lower entrepreneurial quality.

\subsection{Alternative specifications}

The online appendix to this paper shows results for a number of alternative specifications of the main analysis. The alternative specifications include using different matching procedures, matching criteria, and control variables. Overall, the results from the alternative specifications are consistent with the main results.

\section{Conclusion}

Financial constraints are frequently cited as a main barrier to entrepreneurship. Evidence of such financial constraints has previously been identified either in cross-sectional tests of the propensity to become an entrepreneur or in surveys of aspiring entrepreneurs. Although the evidence is consistent with the existence of financial constraints, prior literature has not presented a formal test of the underlying causes of the apparent financial constraint. We propose and examine a simple explanation for the apparent financial constraints to entrepreneurship. We conjecture that a well-functioning capital market would fund able entrepreneurs and constrain individuals with lower entrepreneurial quality. Using a natural experiment to generate exogenous 
variation in wealth, we test this hypothesis by identifying a group of previously constrained individuals, who become entrepreneurs after receiving the windfall. We compare the performance of these businesses with the performance of businesses established by unconstrained entrepreneurs. We find large differences in performance, consistent with our hypothesis that individuals face financial constraint as a result of low entrepreneurial quality.

\section{References}

Abadie, A., and G. W. Imbens. 2006. Large sample properties of matching estimators for average treatment effects. Econometrica 74:235-67.

Altonji, J. G., and T. A. Dunn. 2000. An intergenerational model of wages, hours, and earnings. Journal of Human Resources 35:221-58.

Andersen, S., and K. M. Nielsen. 2011. Participation constraints in the stock market: Evidence from unexpected inheritance due to sudden death. Review of Financial Studies 24:1667-97.

Blanchflower, D. G., and A. J. Oswald. 1998. What makes an entrepreneur? Journal of Labor Economics 16:26-60.

Charles, K. K., and E. Hurst. 2003. The correlation of wealth across generations. Journal of Political Economy 111:1155-82.

De Meza, D. 2002. Overlending? Economic Journal 112:F17-F31.

Evans, D. S., and B. Jovanovic. 1989. An estimated model of entrepreneurial choice under liquidity constraints. Journal of Political Economy 97:808-27.

Evans, D. S., and L. S. Leighton. 1989. Some empirical aspects of entrepreneurship. American Economic Review 79:519-35.

Fairlie, R. W. 1999. The absence of the African-American owned business: An analysis of the dynamics of self-employment. Journal of Labor Economics 17:80-108.

Fine, J. P., and Gray, R. J. 1999. A proportional hazards model for the subdistribution of a competing risk. Journal of the American Statistical Association 94:496-509.

Gentry, W. M., and R. G. Hubbard. 2001. Entrepreneurship and household saving. Working Paper, Columbia University.

Hamilton, B. H. 2000. Does entrepreneurship pay? An empirical analysis of the returns to self-employment. Journal of Political Economy 108:603-31.

Heckman, J. J., Ichimura, H., and P. Todd. 1998. Matching as an econometric evaluation estimator. Review of Economic Studies 65:261-94.

Hirano, K., and G. W. Imbens. 2004. The propensity score with continuous treatments. In Applied Bayesian modelling and causal inference from incomplete-data perspectives. Ed. A. Gelman and X.-L. Meng, 73-84. West Sussex, England: Wiley InterScience.

Holtz-Eakin, D., D. Joulfaian, and H. S. Rosen. 1994a. Entrepreneurial decisions and liquidity constraints. RAND Journal of Economics 25:334-47.

- 1994b. Sticking it out: Entrepreneurial survival and liquidity constraints. Journal of Political Economy 102:53-75.

Hurst, E., and A. Lusardi. 2004. Liquidity constraints, household wealth, and entrepreneurship. Journal of Political Economy 112:319-47.

Hvide, H. K., and J. Møen. 2010. Lean and hungry or fat and content? Entrepreneurs' wealth and start-up performance. Management Science 56:1242-58. 
Kerr, W. R., and R. Nanda. 2009. Democratizing entry: Banking deregulation, financing constraints, and entrepreneurship. Journal of Financial Economics 94:124-49.

- 2010. Banking deregulations, financing constraints, and firm entry size. Journal of the European Economic Association 8:582-93.

King, R. G., and R. Levine. 1993a. Finance and growth: Schumpeter might be right. Quarterly Journal of Economics 108:717-37.

1993b. Finance, entrepreneurship, and growth. Journal of Monetary Economics 32:513-42.

Kleven, H. J., M. B. Knudsen, C. T. Kreiner, S. Pedersen, and E. Saez. 2011. Unwilling or unable to cheat? Evidence from a tax audit experiment in Denmark. Econometrica 79:651-92.

Lindh, T., and H. Ohlsson. 1996. Self-employment and welfare gains: Evidence from the Swedish lottery. Economic Journal 106:1515-26.

Nanda, R. 2008. Cost of external finance and the selection into entrepreneurship. Working Paper, Harvard Business School.

2011. Entrepreneurship and the discipline of external finance. Working Paper, Harvard Business School.

OECD. 2010. SMEs, Entrepreneurship, and Innovation. OECD Policy Report, Paris.

Quadrini, V. 1999. The importance of entrepreneurship for wealth concentration and mobility. Review of Income and Wealth 45:1-19.

Ret og Råd. 2008. Analyse af den nye arvelov. Report, Copenhagen, Denmark.

Sarada. 2010. The unobserved returns to entrepreneurship. Working Paper, University of California-San Diego.

Slemrod, J. 2007. Cheating ourselves: The economics of tax evasion. Journal of Economic Perspectives 21:25-48.

Stiglitz, J. E., and A. Weiss. 1981. Credit rationing in markets with imperfect information. American Economic Review 71:393-410. 